\title{
Surface Markers of Complement Receptor Lymphocytes
}

\author{
Gordon D. Ross, Robert J. Winchester, Enrique M. Rabellino, and \\ Thomas Hoffman, Division of Hematology-Oncology, Department of \\ Medicine, Cornell University Medical College, and The Rockefeller University, \\ New York 10021
}

\begin{abstract}
A B S T R A C T Normal blood lymphocytes bearing complement receptors (CRL) were divided into two populations, one expressing both $\mathrm{CR}_{1}(\mathrm{C} 4 \mathrm{~b}-\mathrm{C} 3 \mathrm{~b}$ receptor) and $\mathrm{CR}_{2}$ (C3d receptor) and a second expressing only $\mathrm{CR}_{1}$. Nearly all of the population that expressed both $\mathrm{CR}_{1}$ and $\mathrm{CR}_{2}$ also bore membrane surface immunoglobulins (Ig) and Ia antigens. The majority of cells that had only $\mathrm{CR}_{1}$ lacked detectable surface Ig. These $\mathrm{Ig}^{-} \mathrm{CR}_{1}{ }^{+} \mathrm{CR}_{2}{ }^{-}$cells could be distinguished from the majority of monocytes and immature granulocytes, in that the latter ingested latex particles and expressed $\mathbf{C R}_{2}$ as well as $\mathrm{CR}_{1}$. The $\mathrm{Ig}^{-} \mathrm{CR}_{1}{ }^{+}$ cells were further subdivided into an Ia-bearing subpopulation and another that lacked Ia. Among the $\mathrm{Ig}^{-}$ $\mathrm{Ia}^{-} \mathrm{CR}_{1}^{+}$cells, one third formed spontaneous rosettes with sheep erythrocytes while all of the remaining CRL were erythrocyte-rosette negative. Essentially all CRL in normal blood had IgG Fc receptors, but a qualitative heterogeneity in the $\mathrm{Fc}$ receptors of $\mathrm{Ia}^{+} \mathrm{CRL}$ vs. $\mathrm{Ia}^{-}$ CRL was observed in their binding of different immune complex systems.
\end{abstract}

\section{INTRODUCTION}

In several previous studies of complement receptor lymphocytes $(\mathrm{CRL})^{1}$ the dominant finding has been that

Dr. Ross is an Established Investigator of The American Heart Association and an Irma T. Hirschl Career Scientist. His present address is Division of Immunology and Rheumatology, Department of Medicine, The University of North Carolina Medical School, Chapel Hill, N. C. 27514. Dr. Winchester is a recipient of a Research Career Development Award from the National Institutes of Health (KO4-AI-00216). Dr. Rabellino is an Andrew W. Mellon Teacher-Scientist.

Received for publication 8 May 1978 and in revised form 30 June 1978.

${ }_{1}^{1}$ Abbreviations used in this paper: $\mathrm{C}$, complement; $\mathrm{CR}_{1}$, complement receptor type one, the immune adherence $(\mathrm{C} 4 \mathrm{~b}-$ $\mathrm{C} 3 \mathrm{~b})$ receptor; $\mathrm{CR}_{2}$, complement receptor type two, the C3d receptor; CRL, complement receptor lymphocytes; E, erythrocyte; EAC, sheep erythrocyte-rabbit IgM antibody-complement complex; E rosette, spontaneous sheep erythrocyte rosette (1); FcR, Fc receptors; FITC, fluorescein isothiocyanate; Ia antigens, human B cell-specific analogues of murine these cells are heterogeneous in their expression of different types of membrane markers (1-5). Whereas most laboratories were in agreement that the CRL had surface immunoglobulin (Ig) and $\mathrm{Fc}$ receptors $(\mathrm{FcR})$, some CRL did not have detectable surface Ig $(2,4,5)$, and a minor proportion of CRL formed erythrocyte (E) rosettes (6). Thus, there was some question as to whether complement (C) receptor expression was restricted to the bone marrow-derived lymphocyte (Bcell) lineage. Because in the past the only reliable criteria for the identification of human $B$ cells was the demonstration of membrane Ig determinants, the whole question of $\mathrm{Ig}^{-}$CRL was revived when it was shown that the usual techniques for measurement of surface Ig could lead to an overestimation of the proportion of Ig-bearing cells because anti-Ig reagents occasionally bound to $\mathrm{FcR}^{+} \mathrm{Ig}^{-}$cells (7). Recently, human Ia antigens have been shown to be B-cellspecific markers of considerable utility (8), and simultaneous analysis of $\mathrm{Ig}$ and Ia antigens has led to the demonstration of $\mathrm{Ig}^{-} \mathrm{Ia}^{+} \mathrm{B}$ cells $(9,10)$. Thus, the possibility arose that CRL which lack demonstrable Ig could be B cells if they expressed Ia antigens. Finally, any complete characterization of the CRL population should include the distinction of CRL which express either one or the other of two distinct types of $\mathrm{C}$ receptors. Although the majority of CRL contain both types of $\mathrm{C}$ receptors, some normal peripheral blood lymphocytes express only $\mathrm{CR}_{1}$ (C4b-C3b receptor), whereas some other normal tonsil lymphocytes express only $\mathrm{CR}_{2}$ (C3d receptor) $(4,5)$.

The present study was instituted to analytically evaluate the surface markers of the CRL by utilizing a combination of all of these advances in methodology. Normal blood CRL were found to be heterogeneous in their content of $\mathrm{CR}_{1}, \mathrm{CR}_{2}$, surface Ig, Ia antigens, and FcR. The majority of CRL expressed B-cellspecific surface Ig and (or) Ia determinants, whereas

lymphocyte antigens encoded by I-region genes; KLH, keyhole limpet hemocyanin; OVA, ovalbumin; TRITC, tetramethylrhodamine isothiocyanate. 
a small proportion of CRL lacked both Ig and Ia antigens; included among these were a minor proportion of CRL that formed E-rosettes.

\section{METHODS}

Isolation of mononuclear cells and identification of lymphocytes. Mononuclear cell fractions were obtained by density centrifugation $\left(400 \mathrm{~g}\right.$, for $45 \mathrm{~min}$ at $\left.20^{\circ} \mathrm{C}\right)$ from whole or dextran-sedimented, heparinized normal blood, at the density interface formed with $d=1.078 \mathrm{~g} / \mathrm{ml}$ Ficoll-Hypaque (Ficoll, Pharmacia Fine Chemicals Inc., Piscataway, N. J., Hypaque, Winthrop Laboratories, New York) (11, 12). After two washes with phosphate-buffered saline (PBS), the cells were resuspended in Hanks' balanced salt solution and incubated with $1.1 \mu \mathrm{m}$ latex particles for $1 \mathrm{~h}$ at $37^{\circ} \mathrm{C}(12)$. After removal of free latex particles by three washes with warm PBS at $400 \mathrm{~g}$ for $10 \mathrm{~min}$, the cells were resuspended in PBS that contained $1 \%$ bovine serum albumin and $0.2 \% \mathrm{NaN}_{3}$ and examined for the extent of latex ingestion by phagocytic cells. For this purpose, air-drained cell smears were stained for peroxidase containing cells (13), followed by staining with Wright-Giemsa. From 10 to $35 \%$ of mononuclear cells ingested latex and this included an average of $95 \%$ of the monocytes and granulocytes simultaneously identified by peroxidase and Wright-Giemsa staining. Thus, 97-99\% of the latex ingestion-negative cells were lymphocytes.

Assay for $C R_{1}$ and $C R_{2}$-bearing cells. $\mathrm{CR}_{1}$ and $\mathrm{CR}_{2}$ were detected as previously described by rosette formation with sheep erythrocyte-rabbit IgM antibody-complement complexes (EAC): EAC14b, EAC1-3b, and EAC1-3d prepared with purified human $\mathrm{C}$ components (14).

Preparation of fluorochrome-conjugated anti-Ig. Rabbit antisera specific for immunoglobulin $\mu$-, $\delta$-, $\alpha$-, and $\gamma$-heavy chains and $\kappa$ - and $\lambda$-light chains were prepared and appropriately absorbed on solid phase immunoabsorbants. After isolation of IgG antibody from each antiserum by DEAE cellulose chromatography (12), each anti-Ig type was divided into two parts, one that was treated with pepsin (Worthington Biochemical Corp., Freehold, N. J.) to produce $\mathrm{F}\left(\mathrm{ab}^{\prime}\right)_{2}$ fragments (15), and the other that was retained as whole IgG. The minimum amount of pepsin required for complete cleavage of all IgG was separately determined with each antibody by pilot studies analyzed by electrophoresis in sodium dodecyl sulfate-polyacrylamide gels. In some instances, the duration that the isolated IgG was stored before digestion and the particular preparation of pepsin necessitated adjustment of the time and concentration of pepsin used for digestion. $F\left(a b^{\prime}\right)_{2}$ fragments were separated from trace amounts of uncleaved IgG and from $\mathrm{pFc}$ fragments by gel filtration on a $5 \times 150-\mathrm{cm}$ column of either Sephacryl S-200 or Sephadex G-150 (Pharmacia Fine Chemicals Inc.) equilibrated with $0.05 \mathrm{M}$ Tris citrate buffer $\mathrm{pH} 8.0$ that contained $1.0 \mathrm{M} \mathrm{NaCl}$. The $\mathrm{F}\left(\mathrm{ab}^{\prime}\right)_{2}$ fragments were shown to be free of uncleaved IgG and $\mathrm{pFc}$ fragments by sodium dodecyl sulfate-polyacrylamide gel electrophoresis and by immunodiffusion analysis with goat anti-rabbit $\mathrm{Fc}_{\mathrm{c}}$ fragment specific serum. Any trace amounts of uncleaved IgG antibody were removed by absorption with Protein A-Sepharose (Pharmacia Fine Chemicals Inc.). Both the whole IgG and $\mathrm{F}\left(\mathrm{ab}^{\prime}\right)_{2}$-anti-Ig were conjugated to tetramethylrhodamine isothiocyanate (TRITC), and conjugate fractions eluting from DE-52 Cellulose (Whatman, Inc., Clifton, N. J.) columns with $0.05-0.125 \mathrm{M} \mathrm{NaCl}$ in $0.01 \mathrm{M}$ sodium phosphate $\mathrm{pH} 7.5$ were used to stain cells $(16,17)$. Each TRITC-anti-Ig conjugate was tested for both specificity and potency in fluorescence staining of lymphoid cell lines. Additional absorptions were made according to the analyses of the patterns of fluorescence staining obtained with either various established lymphoblastoid cell lines or chronic lymphatic leukemic lymphocytes known to contain only one particular heavy chain class and light chain type. In subsequent tests with normal lymphocytes, the anti-Ig reagent was used at a two to fourfold higher concentration than that which gave the maximum number and fluorescence intensity of stained cells.

Immunofluorescence assay for surface $I g, F c R$, and Ia antigens. Direct immunofluorescence staining of surface Ig was performed with either the whole IgG or $\mathrm{F}\left(\mathrm{ab}^{\prime}\right)_{2}$-anti-Ig TRITC conjugate as previously described $(12,17)$. FcR were detected by fluorescence assay with soluble fluorochromeconjugated immune complexes prepared at antibody excess $(12,18)$. Ia antigens were fluorescence stained with a rabbit $\mathrm{F}\left(\mathrm{ab}^{\prime}\right)_{2}$ anti-Ia-fluorescein isothicyanate (FITC) (or TRITC) conjugate, prepared and tested as described previously (9).

Spontaneous sheep erythrocyte rosettes (E-rosettes), thymusderived lymphocyte (T-cell)-enriched, and T-cell-depleted fractions. E rosettes were formed with either neuraminidasetreated sheep E (19) or with untreated $E$ in the presence of heat-inactivated human $\mathrm{AB}$ serum at $4^{\circ} \mathrm{C}(20)$. T-cell-enriched and $\mathrm{T}$-cell-depleted fractions were prepared from mononuclear cell fractions by separation of E-rosettes on FicollHypaque gradients (20). E-rosette depleted fractions contained $<2 \%$ E rosettes, $50 \%$ latex-positive monocytes, and $30-40 \%$ Ia-positive lymphocytes. T-cell fractions prepared from the E-rosette pellet fractions by lysis of sheep E (20), contained 98-99\% E-rosette-forming cells and only $0.5-1.0 \%$ of cells that expressed Ia determinants.

Double and triple marker assays. Cells were stained simultaneously with a TRITC-conjugated reagent specific for either Ig, Ia antigens or FcR, and (or) an FITC-conjugated reagent specific for either Ia antigens or $\mathrm{FcR}$, and then mixed with EAC to form $\mathrm{C}$ receptor-dependent rosettes. All possible combinations of one, two, or three different markers on individual cells were separately enumerated by sequential examination of each microscopic field with blue light fluorescence (FITC), green light fluorescence (TRITC), and visible light phase contrast optics (rosettes).

\section{RESULTS}

$C$ Receptor type of normal blood CRL. When the normal blood lymphocytes from 21 normal individuals were tested for EAC rosette formation, an average of $17.0 \%$ of lymphocytes formed rosettes with either EAC $14 \mathrm{~b}\left(\mathrm{CR}_{1}\right.$ specific $)$ or EAC1-3b, whereas only $9.7 \%$ of lymphocytes formed rosettes with EACl-3d $\left(\mathrm{CR}_{2}\right.$ specific). Because in each individual a mixture of EAC14b and EAC1-3d did not yield more rosetted lymphocytes than did EACl4b alone, $\mathrm{CR}_{2}$-bearing cells were concluded to be a subpopulation of $\mathrm{CR}_{1}$ bearing cells. Normal blood thus contained two populations of CRL, $9.7 \% \mathrm{CR}_{1}{ }^{+} \mathrm{CR}_{2}{ }^{+}$cells, and $7.3 \% \mathrm{CR}_{1}{ }^{+}$ $\mathrm{CR}_{2}{ }^{-}$cells, representing a combined total of $17.0 \%$ CRL. Because all normal blood CRL contained $\mathrm{CR}_{1}$, the total number of CRL could be determined by rosette formation with either EAC14b or EAC1-3b.

Expression of surface Ig and Ia determinants on $C R L$. Normal lymphocytes from 21 individuals were stained with either whole IgG anti-Ig or $\mathrm{F}\left(\mathrm{ab}^{\prime}\right)_{2}$ anti-Ig specific for all heavy chain classes and light chain types, 
and then the stained lymphocytes were assayed for EAC rosette formation (Table I). Whole IgG-anti-Ig and the $\mathrm{F}\left(\mathrm{ab}^{\prime}\right)_{2}$ derivative detected similar proportions of $\mathrm{Ig}^{+} \mathrm{CR}^{+}$and $\mathrm{Ig}^{-} \mathrm{CR}^{+}$cells. However, the whole IgG-anti-Ig detected significantly more $\mathrm{Ig}^{+} \mathrm{CR}^{-}$cells than did the $F\left(a b^{\prime}\right)_{2}$ anti-Ig. Studies with heavy chain class-specific antibodies demonstrated that in most cases, nearly the same proportion of these $\mathrm{Ig}^{+} \mathrm{CR}^{-}$cells were detected with whole IgG-anti- $\gamma$ as with the whole IgG polyvalent reagent, and that $\mathrm{F}\left(\mathrm{ab}^{\prime}\right)_{2}$ anti- $\gamma$ stained only rare $(<0.2 \%) \mathrm{CR}^{-}$cells. However, it was also observed that in $15 \%$ of the normal individuals examined, whole IgG-anti- $\mu, \delta$ detected $10-50 \%$ more $\mathrm{Ig}^{+}$cells than did the $F\left(a b^{\prime}\right)_{2}$-anti- $\mu, \delta$ derivative. The $F\left(a b^{\prime}\right)_{2}$ anti-Ig, rather than the whole IgG anti-Ig, was used in all subsequent assays for surface Ig.

Surface Ig was detected on nearly all $\mathbf{C R}_{\mathbf{2}}$-bearing cells, however $2.0 \%$ of cells expressed Ig and lacked $\mathrm{CR}_{2}$ and $0.3 \%$ expressed $\mathrm{Ig}$ and lacked $\mathrm{CR}_{1}\left(\mathrm{Ig}^{+}, \mathrm{CR}^{-}\right.$, Table I). By contrast, one third of $\mathbf{C R}_{1}$-bearing cells lacked surface $\operatorname{Ig}\left(5.7 \% \mathrm{Ig}^{-} \mathrm{CR}^{+}\right)$. Thus, among the two normal blood CRL populations, most of the $\mathrm{CR}_{1}{ }^{+} \mathrm{CR}_{2}{ }^{+}$ cells contained surface $\mathrm{Ig}\left(9.4 \% \mathrm{Ig}^{+}\right.$vs. $\left.0.5 \% \mathrm{Ig}^{-}\right)$, whereas most of the $\mathrm{CR}_{1}{ }^{+} \mathrm{CR}_{2}{ }^{-}$cells lacked surface Ig $\left(11.3 \%-9.4 \%=1.9 \% \mathrm{Ig}^{+}\right.$vs. $\left.5.7 \% \mathrm{Ig}^{-}\right)$. To characterize further the $\mathrm{Ig}^{-} \mathrm{CR}_{1}{ }^{+}$cells, $\mathrm{CR}_{1}$-bearing cells were examined simultaneously for surface Ig and Ia antigens by triple-marker assay (Table II). All $\mathrm{Ig}^{+} \mathrm{CR}_{1}{ }^{+}$ cells contained Ia antigens $(11.2 \%$ of cells from 8 individuals), whereas less than half of the $\mathrm{Ig}^{-} \mathrm{CR}_{1}{ }^{+}$ cells contained $\mathrm{Ia}$ antigens $\left(\mathrm{Ia}^{+}\right.$cells, $\left.2.4 \%\right)$. The remaining $\mathrm{Ig}^{-} \mathrm{CR}_{1}{ }^{+}$cells lacked detectable Ia determinants ( $\mathrm{Ia}^{-}$cells, $3.2 \%$ ). In all individuals examined, an average of $1.6 \%$ of cells bore Ia determinants but lacked both $\mathrm{CR}_{1}$ and Ig determinants. In phase contrast microscopy, these $\mathrm{Ia}^{+}$cells were predominantly medium to large sized mononuclear cells with little or no visible cytoplasm and a smooth outer membrane.

TABLE I

Combined Assay of Normal Blood Lymphocytes for Surface Ig and C Receptors (CR)

\begin{tabular}{lccc}
\hline & \multicolumn{3}{c}{ Receptor combinations detected } \\
\cline { 2 - 4 } \multicolumn{1}{c}{ Reagents used } & $\mathbf{I g}^{+} \mathbf{C R}^{+}$ & $\mathbf{I g}^{+} \mathbf{C R}^{-}$ & $\mathbf{I g}^{-} \mathbf{C R}^{+}$ \\
\hline & & $\%$ & \\
Whole IgG-anti-Ig* plus & & & \\
EAC1-3b $\left(\mathbf{C R}_{1}\right)$ & $11.7 \ddagger$ & 2.2 & 5.3 \\
EAC1-3d $\left(\mathbf{C R}_{2}\right)$ & 9.2 & 4.6 & 0.3 \\
F(ab') ${ }_{2}$ anti-Ig* plus & & & \\
EAC1-3b $\left(\mathbf{C R}_{1}\right)$ & $11.3 \ddagger$ & 0.3 & 5.7 \\
EAC1-3d $\left(\mathbf{C R}_{2}\right)$ & 9.4 & 2.0 & 0.5 \\
\hline
\end{tabular}

* Polyvalent, specific for $\mu$-, $\delta-, \gamma-, \alpha-, \kappa$-, and $\lambda$-determinants. $\$$ Averages from assay of 21 normal individuals.
TABLE II

Heterogeneity of Ia Expression on Ig-Negative CRL as Compared to Ig-Positive CRL

\begin{tabular}{cccl}
\hline & $\mathrm{Ia}^{+}$ & $\mathrm{Ia}^{-}$ \\
\hline & & $\%$ & \\
$\mathrm{Ig}^{-} \mathrm{CR}_{1}^{+}$ & $2.4^{*}$ & 3.2 \\
$\mathrm{Ig}^{+} \mathrm{CR}_{1}^{+}$ & 11.2 & 0 \\
\hline
\end{tabular}

* Averages from assay of eight normal individuals.

Exclusion of monocytes and immature granulocytes. The majority of nonlymphoid cells ingested latex particles and were thus readily identified and excluded from surface marker determinations. Also, large cells with either an uneven outer membrane or a granular cytoplasm were excluded from surface marker counts regardless of whether or not they ingested latex. However, because some rare peroxidase-positive latexnegative cells were smaller than typical monocytes and contained few granules, additional tests were performed to determine if some of the $\mathrm{Ig}^{-} \mathrm{CR}_{1}{ }^{+}$cells were nonlymphoid cells. Simultaneous Wright-Giemsa and peroxidase staining of EAC rosettes revealed that nearly all peroxidase-positive, latex-negative cells were $\mathrm{CR}_{2}{ }^{+}$, and in this way differed from $\mathrm{Ig}^{-} \mathrm{CR}_{1}{ }^{+}$ lymphocytes that were $\mathrm{CR}_{2}{ }^{-}$(Table I). In addition, it was found that depletion of adherent cells on plastic Petri dishes (5) had no effect on the proportions of $\mathrm{Ig}^{-} \mathrm{CR}_{1}{ }^{+}$lymphoid cells.

Heterogeneity of FCR on CRL. Soluble FITClabeled immune complexes were formed with a variety of different antigen-antibody systems. At antibody concentrations of $1-3 \mathrm{mg} / \mathrm{ml}$, bright staining of $12-15 \%$ of blood lymphocytes was obtained with each of the different immune complex systems. Despite their producing nearly equivalent proportions of stained cells, it was also observed that two of these immune complex systems stained CRL while two other systems predominantly stained non-CRL. It was necessary to use a mixture of two of these systems to detect FcR on both CRL and non-CRL simultaneously. Of the two systems that bound to CRL, sheep anti-IgA and IgA was preferable to sheep anti-rabbit IgG $\mathrm{F}\left(\mathrm{ab}^{\prime}\right)_{2}$ and rabbit IgG $F\left(a b^{\prime}\right)_{2}$ because of the possible interference with other rabbit antibodies used in other simultaneous marker assays. Because no other immune complexes were available that had this selective affinity for CRL, certain additional controls were performed to assure that the sheep anti-IgA system was specific for FcR. First, parallel assay of each lymphocyte preparation with uncomplexed anti-IgA alone stained only $0.3 \%$ of cells, confirming that the assay was not detecting a large proportion of cells bearing surface IgA. Second, no fluorescence staining was observed when immune complexes were prepared with the IgA antigen plus 
$\mathrm{F}\left(\mathrm{ab}^{\prime}\right)_{2}$ anti-IgA rather than intact IgA antibody. Thus, the assay was specific for cells bearing receptors for $\mathrm{F}_{\mathrm{c}}$ contained in immune complexes.

Examination of FITC-immune complex-stained cells for EAC1-3b rosette formation revealed that while the sheep anti-IgA complexes primarily stained $\mathrm{CR}_{1}{ }^{+}$cells, complexes formed with either rabbit anti-ovalbumin (OVA) and OVA or rabbit anti-keyhole limpet hemocyanin $(\mathrm{KLH})$ and $\mathrm{KLH}$ primarily stained $\mathrm{CR}_{1}{ }^{-}$cells. The absence of staining on $\mathrm{CR}_{1}{ }^{+}$cells was most pronounced with the anti-OVA-OVA complexes, and on some occasions, KLH complexes stained some $\mathrm{CR}_{1}{ }^{+}$ cells in addition to $\mathrm{CR}_{1}{ }^{-}$cells. However, when this was observed, the brightest fluorescence staining with these $\mathrm{KLH}$ complexes was on $\mathrm{CR}_{1}{ }^{-}$cells, and the staining of $\mathrm{CR}_{1}{ }^{+}$cells was noticeably weaker.

Either FITC-sheep anti-IgA-IgA or rabbit anti-OVAOVA immune complexes or a mixture of these two types of complexes was used to label $\mathrm{FcR}$ in combination with TRITC-F $\left(\mathrm{ab}^{\prime}\right)_{2}$-anti-Ia and EAC1-3b for simultaneous assay of Ia antigens and $\mathrm{CR}_{1}$ (Table III). With anti-OVA-OVA complexes, the majority of cells labeled were $\mathrm{Ia}^{-} \mathrm{CR}_{1}{ }^{-}(11.7 \%)$. Among the $\mathrm{CR}_{1}{ }^{+}$cells, nearly all of the $\mathrm{Ia}^{-} \mathrm{CR}_{1}{ }^{+}$cells were stained $(3.2 \%)$, whereas only a small proportion of $\mathrm{Ia}^{+} \mathrm{CR}_{1}{ }^{+}$cells were stained (1.2\%). Anti-IgA-IgA complexes differed from the anti-OVA-OVA complexes in that they predominantly labeled $\mathrm{Ia}^{+} \mathrm{CR}_{1}{ }^{+}$cells $(13.4 \%)$ and bound to few $\mathrm{Ia}^{-} \mathrm{CR}_{1}^{-}$cells $(0.4 \%)$.

The heterogeneity of immune complex binding to different cell populations was further revealed when cells were simultaneously stained with the anti-IgA complexes plus the anti-OVA complexes (Table III). FcR were detected on both $\mathrm{Ia}^{+}$and $\mathrm{Ia}^{-} \mathrm{CRL}$, and in addition, $\mathrm{FcR}$ were detected on $12 \% \mathrm{Ia}^{-} \mathrm{CR}_{1}{ }^{-}$cells. Clearly, there were more than $28 \%$ FcR-bearing cells, the majority of which bound either one or the other of the two immune complexes examined.

Expression of $\mathrm{CR}_{1}$ on Cells forming Erosettes. Because $3 \%$ of normal blood lymphocytes contained $\mathrm{CR}_{1}$ but lacked detectable B-cell-specific Ig and Ia de-

TABLE III

Detection of FcR on Ia-Positive-vs. Ia-Negative-CRL with Different Immune Complex Systems

\begin{tabular}{lccr}
\hline \multirow{2}{*}{$\begin{array}{c}\text { Immune complex } \\
\text { type }\end{array}$} & \multicolumn{3}{c}{$\mathrm{FcR}^{+}$cells detected } \\
\cline { 2 - 4 } & $\mathrm{Ia}^{+} \mathrm{CR}_{1}{ }^{+}$ & $\mathrm{Ia}^{-} \mathrm{CR}_{1}{ }^{+}$ & $\mathrm{Ia}^{-} \mathrm{CR}_{1}{ }^{-}$ \\
\hline $\begin{array}{l}\text { Anti-OVA-OVA } \\
\text { Anti-IgA-IgA }\end{array}$ & $1.2^{*}$ & 3.2 & 11.7 \\
$\begin{array}{c}\text { Anti-OVA-OVA plus } \\
\text { anti-IgA-IgA }\end{array}$ & 13.4 & 0.3 & 0.4 \\
\hline
\end{tabular}

* Averages from assay of five normal individuals.
TABLE IV

$C R_{1}$ and Ia Expression in E-Rosette-Negative and E-Rosette-Positive (T-Cell) Fractions Isolated from Normal Blood

\begin{tabular}{lcccc}
\hline & \multicolumn{4}{c}{ Marker combinations detected } \\
\cline { 2 - 5 } Lymphocyte fraction & $\mathrm{Ia}^{+} \mathrm{CR}_{\mathbf{1}}{ }^{+}$ & $\mathbf{I a}^{+} \mathbf{C R}_{\mathbf{1}}{ }^{-}$ & $\mathbf{I a}^{-} \mathbf{C R}_{1}{ }^{+}$ & $\mathbf{I a}^{-} \mathbf{C R}_{1}{ }^{-}$ \\
\hline & \multicolumn{5}{c}{$\%$} \\
Unseparated cells & $13.6 *$ & 1.9 & 3.5 & 81 \\
E-rosette-negative & 56 & 7 & 12 & 25 \\
E-rosette-positive & 0.6 & 0.1 & 1.6 & 98 \\
\hline
\end{tabular}

* Averages from assay of five normal individuals.

terminants, assays were performed to determine if some $\mathrm{CR}_{1}$-bearing cells expressed the $\mathrm{T}$-cell marker of E-rosette formation. Normal blood lymphocytes forming $\mathbf{E}$ rosettes were separated from E-rosette-negative lymphocytes by Ficoll-Hypaque centrifugation, and then each of the two lymphocyte fractions was examined by double-marker assay for EAC1-3b rosette formation and Ia antigens. E-rosette-negative fractions contained the vast majority of $\mathrm{Ia}^{+}$cells and $<2 \%$ contamination with E rosettes. By contrast, 98-99\% of cells in E-rosette ( $\mathrm{T}$-cell) fractions formed $\mathrm{E}$ rosettes and only $0.5-1.0 \%$ of cells expressed Ia antigens. The majority of cells in the E-rosette-negative fractions contained $\mathrm{CR}_{1}$, and these included $12 \% \mathrm{Ia}^{-} \mathrm{CR}_{1}{ }^{+}$cells (Table IV). By contrast, only $2.1 \% \mathrm{CR}_{1}{ }^{+}$cells were detected in $\mathrm{T}$-cell fractions, including $1.6 \% \mathrm{Ia}^{-} \mathrm{CR}_{1}{ }^{+}$ cells. Even though B-cell fractions contained a much higher proportion of $\mathrm{Ia}^{-} \mathrm{CR}_{1}{ }^{+}$cells than did T-cell fractions, the B-cell fractions represented only $18 \%$ of the unseparated lymphocytes, whereas the $\mathrm{T}$-cell fractions contained the remaining $82 \%$ of lymphocytes. Thus, it could be calculated that whole blood contained $2.2 \%$ (18\% of $12 \%$ ) E-rosette-negative $\mathrm{Ia}^{-} \mathrm{CR}_{1}{ }^{+}$cells and $1.3 \%(82 \%$ of $1.6 \%)$ of E-rosette-positive $\mathrm{Ia}^{-} \mathrm{CR}_{1}{ }^{+}$cells.

Parallel assay for EAC $1-3 \mathrm{~d}$ rosette formation in these same $\mathrm{T}$-cell fractions revealed only $0.3 \% \mathrm{CR}_{2}$-bearing cells, all of which contained Ia determinants (data not shown). Thus, the E-rosette marker was associated with only a minor proportion of $\mathrm{CR}_{1}$-bearing cells and was absent from $\mathrm{CR}_{2}$-bearing cells.

\section{DISCUSSION}

The expression of $\mathrm{C}$ receptors is a well-recognized property of B cells, but there have been several conflicting reports of $\mathrm{C}$ receptors also present on $\mathrm{T}$ cells (6) and non-B cells active in antibody dependent cellular cytotoxicity $(21,22)$. The present study was undertaken because of the advent of several improved methods for detection of membrane markers and the availability of Ia as a reliable B-cell marker on Ig-posi- 
tive and some Ig-negative lymphocytes. Although Bcell-specific surface Ig or Ia antigens were detected on the majority of CRL, a minor proportion of CRL lacked these markers and these included some CRL that apparently expressed the T-cell marker of $\mathrm{E}$ rosette formation. FcR were detected on all normal blood CRL, but qualitative differences in the $\mathrm{FcR}$ of $\mathrm{Ia}^{+} \mathrm{CRL}$ vs. Ia ${ }^{-}$CRL were recognized by their preferential binding of one or the other of two different immune complex systems.

In the past, many different types of studies have been performed in an attempt to determine whether the CRL were members of either the B- or T-lymphocyte population $(23,24)$. The first of such studies in mice demonstrated that the majority of CRL were killed by anti-Ig and C (23), whereas conversely the proportion of CRL was increased by treatment of lymphocytes with anti-thy-1 and C (25). Thus, the CRL were part of the Ig-bearing B-cell population but not the thy-1 bearing T-cell population. Subsequent direct studies with human lymphocytes demonstrated surface Ig by immunofluorescence on cells forming EAC rosettes, and an absence of $\mathrm{C}$ receptors on $\mathrm{T}$ cells forming E-rosettes $(1,2)$. However, whereas initial studies with whole IgG anti-Ig reagents indicated that all human blood CRL contained membrane Ig, significant proportions of $\mathrm{Ig}^{-} \mathrm{CRL}$ were also observed with these same reagents in both tonsils and spleen $(2,5)$. This apparent inconsistency was a stimulus to the present study, especially with the advent of more reliable methods for detecting surface Ig and because of the availability of surface Ia as an additional B-cell marker.

A variety of different observations on the selective expression of human Ia determinants has made it increasingly evident that Ia is a more reliable marker of cells in the B-lymphocyte lineage than is surface Ig. Among normal lymphoid cells, nearly all Ig-bearing cells and plasma-cell precursors express Ia, whereas Ia is undetectable on the vast majority of non-B and T lymphocytes $(9,10,26)$. Furthermore, supporting evidence for Ia expression on Ig-negative pre-B cells has been provided by the demonstration of such characteristic pre-B cells in both normal marrow and marrow from patients with infantile hypogammaglobulinemia (27). Similarly, the essential absence of such $\mathrm{Ia}^{+} \mathrm{Ig}^{-}$cells in the blood from patients with infantile agammaglobulinemia supports the current concept that this disease results from a lesion in the developmental pathway of early B cells (10). In general, the assay of Ia antigens as a B-cell marker has certain advantages over surface Ig analysis. The interpretation of surface Ig data is complicated by the changing relationship of surface IgM and IgD during differentiation, as well as by the absence of Ig from pre-B cells and activated cells. In addition, technical problems in the analysis of $\mathrm{Ig}$ can result from the presence of either autoantibodies to lymphocytes or FcR capable of binding immune complexes and serum IgG. However, it should also be emphasized that surface Ia analysis has other drawbacks that require caution. Some monocytes have surface Ia and B cells ultimately lose detectable Ia determinants during the terminal differentiation process into plasma cells (28).

The present studies illustrated the differences between whole IgG anti-Ig and $F\left(a b^{\prime}\right)_{2}$ anti-Ig reagents that were derived from the same antisera and demonstrated to have the same specificity and potency. This difference was still apparent after a 1-h incubation and three washes in $37^{\circ} \mathrm{C}$ buffer, suggesting that small quantities of plasma Ig may still have been present. Moreover, these experiments demonstrate that a considerable proportion of the cells labeled with the whole IgG-anti-Ig reagent were not labeled with the $F\left(a b^{\prime}\right)_{2}$ anti-Ig derivative and lacked $\mathrm{C}$ receptors entirely. These presumably represent the $\mathrm{T}$ cells with $\mathrm{FcR}$ previously identified as cells that secondarily bind the fluorescent reagent in complexed form (7). Even though in most normal individuals there was little difference in the proportion of positive cells detected with whole IgG anti- $\mu, \delta$ vs. $F\left(a^{\prime}\right)_{2}$ anti- $\mu, \delta$, it was also found, in some occasional individuals, that whole IgG-anti- $\mu, \delta$ stained $10-50 \%$ more lymphocytes than did its $F\left(a b^{\prime}\right)_{2}$ derivative. Thus, for detection of membrane IgM and IgD, as well as IgG, it is preferable to use $\mathrm{F}\left(\mathrm{ab}^{\prime}\right)_{2}$ rather than whole IgG antibodies.

Tests with mixtures of EAC types confirmed previous findings $(2,5)$ that $\mathbf{C R}_{2}$-bearing cells $(9.7 \%$ of lymphocytes) were a subpopulation of $\mathbf{C R}_{1}$-bearing cells ( $17.0 \%$ of lymphocytes). All normal blood CRL could be detected by rosette formation with either EAC14b or EACl-3b but not with EAC1-3d. Nearly all cells bearing both $\mathrm{CR}_{1}$ and $\mathrm{CR}_{2}$ expressed $\mathrm{Ig}$, whereas more than $5 \%$ of normal blood lymphocytes expressed $\mathrm{CR}_{1}$ but not $\mathrm{CR}_{2}$ and these lacked detectable membrane Ig. However, the $\mathrm{CR}_{2}$ assay does not detect all normal $\mathrm{B}$ cells, because an average of $2 \%$ of lymphocytes expressed surface Ig and lacked $\mathrm{CR}_{2}$.

To exclude the possibility that some $\mathrm{Ig}^{-} \mathrm{CRL}$ might be nonlymphoid cells, EAC-rosetted cells were simultaneously examined for latex ingestion, peroxidase staining, and Wright-Giemsa morphology. Nonlymphoid cells in lymphocyte preparations included monocytes $(20 \%)$ and immature neutrophils (5\%), all of which were stained for peroxidase activity. More than $95 \%$ of peroxidase-positive cells ingested latex particles and thus were excluded from surface marker analysis. The remaining very minor proportion of peroxidase-positive latex-negative cells differed from Ig $^{-}$CRL because most were $\mathrm{CR}_{1}{ }^{+} \mathrm{CR}_{2}{ }^{+}$, whereas $\mathrm{Ig}^{-} \mathrm{CRL}$ were $\mathrm{CR}_{1}{ }^{+}$ $\mathrm{CR}_{2}{ }^{-}$. Indeed, previous studies of monocytes (29) and 
immature neutrophils (30) have demonstrated that these cells very rarely express $\mathrm{CR}_{1}$ in the absence of $\mathrm{CR}_{2}$ and commonly contain either no $C$ receptors, $\mathrm{CR}_{2}$, or $\mathrm{CR}_{2}$ plus $\mathrm{CR}_{1}$. Thus, it is likely that most, if not all of the $\mathrm{Ig}^{-} \mathrm{CR}_{1}{ }^{+}$cells identified in the present study were lymphocytes.

Of these $\mathrm{Ig}^{-} \mathrm{CR}_{1}{ }^{+}$cells, slightly less than half bore Ia determinants and these were presumably $\mathrm{Ig}^{-}$ members of the B-lymphocyte lineage.

Essentially all CRL were demonstrated to have FcR, however several different types of $\mathrm{FcR}$ assay systems were required to demonstrate $\mathrm{FcR}$ on the entire $\mathrm{CRL}$ population. This heterogeneity may have been involved in some previous reports that some CRL lacked FcR $(31,32)$. Four different soluble immune complex systems were examined for fluorescence labeling of FcR. Two of the complexes bound primarily to $\mathrm{Ia}^{+}$ cells whereas the other two complexes bound primarily to $\mathrm{Ia}^{-}$cells. Detection of all cells with $\mathrm{FcR}$ required a mixture of two different complexes, one that preferentially bound to $\mathrm{Ia}^{+}$cells and another that preferentially bound to $\mathrm{Ia}^{-}$cells. Other investigators have also reported a heterogeneity of $\mathrm{FcR}$ on $\mathrm{B}$ cells vs. non-B cells $(33,34)$.

Table V summarizes the findings of this study. Five different CRL subsets were defined by the surface markers examined and these included $17 \%$ of peripheral blood lymphocytes. The first subset of CRL contained both $\mathrm{CR}_{1}$ and $\mathrm{CR}_{2}$, while the remaining four subsets contained only $\mathrm{CR}_{1}$. This first subset contains the majority of $\mathrm{Ig}^{+} \mathrm{CRL}$ and would be the only subset detected if EAC1-3d were used to detect CRL. This is probably the explanation of the report that Ig-bearing cells and CRL were a completely overlapping homogeneous population of cells (35), especially in view of the use of EAC prepared with whole mouse serum as a source of $\mathrm{C}$ and thus EACl-3d (4), a preparation that is known to detect primarily only $\mathrm{CR}_{2}$ and fewer normal blood CRL than does an EACl-3b preparation that detects $\mathrm{CR}_{1}(2,4)$. The first three CRL subsets are $\mathrm{B}$ cells because of their content of surface Ia determinants $(8-10)$. These three B-cell CRL subsets may reflect

TABLE V

Surface Marker-Defined Subsets of Normal Blood CRL

\begin{tabular}{llcc}
\hline $\begin{array}{c}\text { C receptor } \\
\text { type }\end{array}$ & Surface markers & Proportion & $\begin{array}{c}\text { Probable } \\
\text { lineage }\end{array}$ \\
\hline & & $\%$ & \\
$\mathrm{CR}_{1}, \mathrm{CR}_{2}$ & Ia, FcR, Ig & 9.4 & B cell \\
$\mathrm{CR}_{1}$ & Ia, FcR, Ig & 2.0 & B cell \\
$\mathrm{CR}_{1}$ & Ia, FcR & 2.4 & B cell \\
$\mathrm{CR}_{1}$ & FcR & 2.1 & $?$ \\
$\mathrm{CR}_{1}$ & FcR, E-rosette & 1.1 & ? \\
\hline
\end{tabular}

different stages of lymphocyte differentiation, rather than functionally different cell types. $\mathrm{CR}_{1}, \mathrm{CR}_{2}$, and FcR have been shown to be expressed sequentially during the process of granulocyte differentiation from immature bone marrow cells $(30,36)$, and studies of mouse $B$ lymphocytes have demonstrated a sequential appearance of $\mathrm{C}$ receptors during B-cell maturation (37). The fourth and fifth CRL subset of Table V lacked both Ig and Ia determinants. The fifth subset, representing $1.1 \%$ of blood lymphocytes, not only lacked both Ig and Ia, but also formed $\mathrm{E}$ rosettes, a T-cell marker. However, these cells may not be $\mathrm{T}$ cells as there is an alternate possibility that they may be the $\mathrm{CR}_{1}$-bearing cells that mediate antibody-dependent cellular cytotoxicity $(23,38)$. Final classification of the fourth and fifth CRL subsets will require their isolation and function analysis.

\section{ACKNOWLEDGMENTS}

The authors wish to acknowledge many helpful discussions with Dr. Henry G. Kunkel and are indebted to Miss Chang-Yi Wang for preparation of the heteroantiserum specific for Ia determinants, and to Mrs. Varda Gilad and Ms. Renee Zwiebel-Posner for their excellent technical assistance.

Research for this paper was supported by grants from the National Cancer Institute (CA-16190 and CA-20107), Department of Health, Education, and Welfare.

\section{REFERENCES}

1. Jondal, M., G. Holm, and H. Wigzell. 1972. Surface markers on human $\mathrm{T}$ and B lymphocytes. I. A large population of lymphocytes forming nonimmune rosettes with sheep red blood cells. J. Exp. Med. 136: 207-215.

2. Ross, G. D., E. M. Rabellino, M. J. Polley, and H. M. Grey. 1973. Combined studies of complement receptors and surface immunoglobulin bearing cells and sheep erythrocyte rosette-forming cells in normal and leukemic human lymphocytes. J. Clin. Invest. 52: 377-385.

3. Möller, G. 1974. Effect of B cell mitogens on lymphocyte subpopulations possessing $\mathrm{C}^{\prime} 3$ and Fc receptors. $J$. Exp. Med. 139: 969-982.

4. Ross, G. D., M. J. Polley, E. M. Rabellino, and H. M. Grey. 1973. Two different complement receptors on human lymphocytes: one specific for $\mathrm{C} 3 \mathrm{~b}$ and one specific for C3b inactivator-cleaved C3b. J. Exp. Med. 138: 798811.

5. Ross, G. D., and M. J. Polley. 1975. Specificity of human lymphocyte complement receptors. J. Exp. Med. 141: 116.3-1180.

6. Mendes, N. F., S. S. Miki, and Z. F. Peixinho. 1974. Combined detection of human $\mathrm{T}$ and $\mathrm{B}$ lymphocytes by rosette formation with sheep erythrocytes and zymosanC3 complexes. J. Immunol. 113: 531-536.

7. Winchester, R. J., S. M. Fu, T. Hoffman, and H. G. Kunkel. 1975. IgG on lymphocyte surfaces; technical problems and the significance of a third cell population. J. Immunol. 114: 1210-1212.

8. Winchester, R. J., S. M. Fu, P. Wernet, H. G. Kunkel, B. Dupont, and C. Jersild. 1975. Recognition by pregnancy serums of non-HL-A alloantigens selectively expressed on B lymphocytes. J. Exp. Med. 141: 924-929. 
9. Winchester, R. J., C. Y. Wang, J. Halper, and T. Hoffman. 1976. Studies with B-cell allo- and hetero-antisera: parallel reactivity and special properties. Scand. J. Immunol. 5: 745-757.

10. Hoffman, T., C. Y. Wang, R. J. Winchester, M. Ferrarini, and H. G. Kunkel. 1977. Human lymphocytes bearing Ia-like antigens; absence in patients with infantile agammaglobulinemia. J. Immunol. 119: 15201524.

11. Bøyum, A. 1968. Separation of leukocytes from blood and bone marrow. Scand. J. Clin. Lab. Invest. Suppl. 21: $97-108$.

12. Winchester, R. J., and G. Ross. 1976. Enumeration of lymphocyte populations. In Manual of Clinical Immunology. N. R. Rose and H. Friedman, editors. American Society for Microbiology, Washington, D. C. 64-76.

13. Kaplow, L. S. 1965. Simplified myeloperoxidase stain using benzidine dihydrochloride. Blood. 26: 215-219.

14. Ross, G. D., and M. J. Polley. 1976. Assay for the two different types of lymphocyte complement receptors. Scand. J. Immunol. 5(Suppl. 5): 99-111.

15. Nisonoff, A., F. C. Wissler, L. N. Lipman, and D. L. Woernley. 1960. Separation of univalent fragments from the bivalent rabbit antibody molecule by reduction of disulfide bonds. Arch. Biochem. Biophys. 89: 230-244.

16. Amante, L., A. Ancona, and L. Fornia. 1972. The conjugation of immunoglobulins with tetramethylrhodamine isothiocyanate. A comparison between the amorphous and crystalline fluorochrome. J. Immunol. Methods. 1: 289-301.

17. Winchester, R. J., and S. M. Fu. 1976. Lymphocyte surface membrane immunoglobulin. Scand. J. Immunol. 5(Suppl. 5): 77-82.

18. Abbas, A. K., and E. R. Unanue. 1975. Interrelationships of surface immunoglobulin and $\mathrm{Fc}$ receptors on mouse B lymphocytes. J. Immunol. 115: 1665-1671.

19. Weiner, M. S., C. Bianco, and V. Nussenzweig. 1973. Enhanced binding of neuraminidase-treated sheep erythrocytes to human $\mathrm{T}$ lymphocytes. Blood. 42: 939-946.

20. Hoffman, T., and H. G. Kunkel. 1976. The E-rosette test. In In Vitro Methods in Cell Mediated and Tumor Immunity. B. R. Bloom and J. R. David, editors. Academic Press Inc., New York. 71-81.

21. Perlmann, P., H. Wigzell, P. Golstein, E. W. Lamon, A. Larson, C. O'toole, H. Perlmann, and E. A. J. Svedmyr. 1974. Cell-mediated cytolysis in vitro: analysis of active lymphocyte subpopulations in different experimental systems. Adv. Biosci. 12: 71-87.

22. Perlmann, P., H. Perlmann, and H. J. Muller-Eberhard. 1975. Cytotoxic lymphocytic cells with complement receptors in human blood. Induction of cytolysis by IgG antibody but not by target cell-bound C3. J. Exp. Med. 141: 287-296.

23. Bianco, C., R. Patrick, and V. Nussenzweig. 1971. A population of lymphocytes bearing a membrane receptor for antigen-antibody-complement complexes. I. Isolation and characterization. J. Exp. Med. 132: 702-720.

24. Bianco, C. 1977. Plasma membrane receptors for complement. In Biological Amplification Systems in Immunology, N. K. Day and R. A. Good, editors. Plenum Publishing Corporation, New York. 69-84.

25. Bianco, C., and V. Nussenzweig. 1971. Theta-bearing and complement receptor lymphocytes are distinct populations of cells. Science (Wash. D. C.). 173: 154-156.

26. Friedman, S. M., J. M. Breard, R. E. Humphreys, J. L. Strominger, S. F. Schlossman, and L. Chess. 1977. Inhibition of proliferative and plaque-forming cell responses by human bone-marrow-derived lymphocytes from peripheral blood by antisera to the p23, 30 antigen. Proc. Natl. Acad. Sci. U. S. A. 74: 711-715.

27. Pearl, E. R., L. B. Vogler, A. J. Okos, W. M. Crist, A. R. Lawton, and M. D. Cooper. 1978. B lymphocyte precursors in human bone marrow: an analysis of normal individuals and patients with antibody-deficiency states. J. Immunol. 120: 1169-1175.

28. Halper, J., S. M. Fu, C. Y. Wang, R. Winchester, and H. G. Kunkel. 1978. Patterns of expression of human "Ia-like" antigens during the terminal stages of B cell development. J. Immunol. 120: 1480-1484.

29. Reynolds, H. Y., J. P. Atkinson, H. H. Newball, and M. M. Frank. 1975. Receptors for immunoglobulin and complement on human alveolar macrophages. J. Immunol. 114: 1813-1819.

30. Ross, G. D., C. I. Jarowski, E. M. Rabellino, and R. J. Winchester. 1978. The sequential appearance of Ia-like antigens and two different complement receptors during the maturation of human neutrophils. J. Exp. Med. 147: 730-744.

31. Lobo, P. I., and D. A. Horwitz. 1976. An appraisal of Fc receptors on human peripheral blood $B$ and $L$ lymphocytes. J. Immunol. 117: 939-943.

32. Lyet, J. P., A. L. Jarge, and D. E. Normansell. 1977. Subpopulations of human peripheral blood lymphocytes. Cell Immunol. 33: 191-202.

33. Arbeit, R. D., P. A. Henkart, and H. B. Dickler. 1977. Differences between the $F_{c}$ receptors of two lymphocyte subpopulations of human peripheral blood. Scand. J. Immunol. 6: 873-878.

34. Winfield, J., P. I. Lobo, and M. E. Hamilton. 1977. Fc receptor heterogeneity: immunofluorescent studies of $B$, $\mathrm{T}$, and "third population" lymphocytes in human blood with rabbit IgG b4-anti-b4 complexes. J. Immunol. 119: 1778-1784.

35. Ehlenberger, A. G., M. McWilliams, J. M. PhillipsQuagliatta, M. E. Lamm, and V. Nussenzweig. 1976. Immunoglobulin-bearing and complement-receptor lymphocytes constitute the same population in human peripheral blood. J. Clin. Invest. 57: 53-56.

36. Rabellino, E. M., G. D. Ross, H. T. K. Trang, N. Williams, and D. Metcalf. 1978. Membrane receptors of mouse leukocytes. II. Sequential expression of membrane receptors phagocytic capacity during leukocyte differentiation. J. Exp. Med. 147: 434-445.

37. Hämmerling, U., A. F. Chin, and J. Abbott. 1976. Ontogeny of murine B lymphocytes: sequence of B cell differentiation from surface immunoglobulin-negative precursors to plasma cells. Proc. Natl. Acad. Sci. U. S. A. 73: 2008-2012.

38. Flad, H.-D., U. Fink, and M. P. Dierich. 1977. K cell activity of normal and chronic lymphocytic leukaemia lymphocytes: association with lymphocytes bearing receptors for human C3b. In Haematology and Blood Transfusion. Immunological Diagnosis of Leukemias and Lymphomas. S. Thierfelder, H. Rodt, and E. Thiel, editors. Springer Verlag, K. G., Berlin. 20: 197-202. 